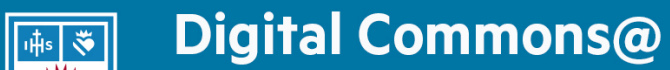

Loyola Marymount University

LMU Loyola Law School

\section{Journal of Catholic Education}

May 2016

\section{The Leadership Challenge: Preparing and Developing Catholic School Principals}

\author{
Michael J. Boyle \\ Andrew M. Greeley Center for Catholic Education, School of Education-Loyola University Chicago \\ Alicia Haller \\ Center for the Study of Education Policy, Illinois State University \\ Erika Hunt \\ Center for the Study of Education Policy, Illinois State University
}

Follow this and additional works at: https://digitalcommons.Imu.edu/ce

Part of the Educational Leadership Commons

\section{Recommended Citation}

Boyle, M. J., Haller, A., \& Hunt, E. (2016). The Leadership Challenge: Preparing and Developing Catholic School

Principals. Journal of Catholic Education, 19 (3). http://dx.doi.org/10.15365/joce.1903152016

This Focus Section Article is brought to you for free with open access by the School of Education at Digital Commons at Loyola Marymount University and Loyola Law School. It has been accepted for publication in Journal of Catholic Education by the journal's editorial board and has been published on the web by an authorized administrator of Digital Commons at Loyola Marymount University and Loyola Law School. For more information about Digital Commons, please contact digitalcommons@lmu.edu. To contact the editorial board of Journal of Catholic Education, please email JCE@nd.edu. 


\title{
The Leadership Challenge: Preparing and Developing Catholic School Principals
}

\author{
Michael J. Boyle \\ Loyola University Chicago \\ Alicia Haller \\ Illinois State University \\ Erika Hunt \\ Illinois State University
}

The increasing emphasis on the myriad of leadership preparation standards have caused university principal preparation programs to necessarily focus on the more secular aspect of leading schools. For the Catholic school principal, this has left little focus on the development of critical strategies to lead for Catholic Identity and faith formation. This article suggests using the National Standards and Benchmarks for Effective Catholic Schools as a framework for Catholic principal preparation programs to address this issues. Additional suggests for program development are also offered.

\section{Keywords}

Catholic schools, principal preparation

$\mathrm{F}$ rom Interstate School Leaders Licensure Consortium (ISLLC), Southern Regional Education Board (SREB), Educational Leadership Constituent Council (ELLC), to various state leadership standards, university principal preparation programs are increasingly responsible for creating programs that use a standards-based approach to form principals. However, "ever-rising accountability standards, limited authority over key decisions, and mediocre pay make the job more and more demanding and less and less attractive to talented leaders" (Doyle \& Locke, 20I4, p. 2).

In Catholic and other faith-based schools, the challenge of finding qualified principals is compounded by the simultaneous responsibility of the prin-

Journal of Catholic Education, Vol. 19, No. 3, May 2016, 293-316. This article is licensed under a Creative Commons Attribution 3.o International License. doi: 10.15365/joce.19031520I6 
cipal as spiritual leader and as educational instructional and managerial leader (Ciriello, 1996). As lay leaders replace religious women and men in Catholic schools dioceses, Congregational sponsors can no longer assume that principal candidates will possess working knowledge of the Catholic faith and Catholic school governance structures or the skills needed to build a faith community within the educational community (NCEA, 2009). Central to the mission of the Church is the work of Catholic schools. The National Standards and Benchmarks for Effective Catholic Elementary and Secondary Catholic Schools (NSBECS) has stated, "An excellent Catholic school has a qualified leader/leadership team empowered by the governing body to realize and implement the school's mission and vision." While the challenges faced by Catholic schools are great, they are exacerbated by the fact that principal preparation programs for a long time did not adequately prepare candidates for the challenges of the principalship. While reform efforts ushered in over the last 15 years have begun to demonstrate more positive results, more improvements are needed-particularly for institutions that wish to meet the needs of those who want to lead Catholic schools.

\section{The Need for Improvements in Principal Preparation}

Quality school leadership is a key component in any reform effort directed at improving student achievement. Empirical evidence demonstrates that principals can create school environments conducive to teaching and learning (Clotfelter, Ladd, Vigdor, \& Wheeler, 2007; Seashore-Lewis, Dretzke, \& Wahlstrom, 20Io), and attract, support, and retain high-quality teachers (Branch, Hanushek, \& Rivkin, 20I3; Clotfelter et al., 2007). In fact, leadership is second only to teaching among school influences on student success, and the impact of leadership is greatest in schools with the greatest needs (Branch, Hanushek, \& Rivkin, 2009; Hallinger \& Heck I998; Leithwood, Seashore Louis, Anderson, \& Wahlstrom 2004). Studies by Leithwood et al. (2004) and Waters, Marzano, and McNulty (2003) indicate that a principal's influence accounts for about one-quarter of school-level variation in student achievement. A meta-analysis by Waters et al. (2003) revealed that increasing leadership effectiveness by one standard deviation could lead to a ro-percentile point gain in student achievement. Another meta-analysis exploring the relationship between leadership and student outcomes identified three leadership domains that had moderate to strong effects on student outcomes (Robinson, Lloyd, \& Rowe, 2008). Cosner and Jones (2016) described 
the leadership domains found to be effective in improving low-performing schools: (a) Setting organization goals and monitoring goal attainment using school-wide data and a cycles of inquiry process for continuous improvement; (b) Promoting teacher learning by building professional development systems that grow teachers' effective practice knowledge and skills; and (c) Serving directly as instructional leader by coordinating and evaluating teaching and curriculum.

Scholars have found that quality instruction throughout an entire school building, rather than isolated pockets of excellence, is rare without the leadership of an effective principal (Hallinger \& Heck, r996; Institute for Educational Leadership, 2000; Leithwood, Anderson \& Wahlstrom, 2004; Waters et al., 2003; Witziers, Bosker, \& Kruger, 2003). In a report that provided a national scan of state policies involving preparing and developing school principals, Paul Manna (2015) described the crucial role of the school principal as a multiplier of effective teaching practice.

Yet, the principal's capacity to work with teachers and enhance student achievement depends on sound academic training. Many scholars point to a report in 2005 by Art Levine, former President of Teachers College at Columbia University, as the catalyst for the current attention being paid to the preparation of school leaders. The Levine Report (2005) scrutinized university-based principal preparation programs based on a four-year study of leadership programs at schools of education across the country. The report included nine criteria for judging principal preparation programs.

I. Purpose The program's purpose is explicit, focusing on the education of practicing school leaders; goals reflect the needs of today's leaders, schools, and children; and the definition of success is tied to student learning in the schools administered by the program graduates.

2. Curricular The curriculum mirrors program purposes and goals. The Coherence curriculum is rigorous, coherent, and organized to teach the skills and knowledge needed by leaders at specific types of schools and at the various stages of their careers.

3. Curricular The curriculum integrates the theory and practice of Balance administration, balancing study in university classrooms and work in schools with successful practitioners. 
4. Faculty The faculty includes academics and practitioners who Composition are experts in school leadership, up to date in their field, intellectually productive, and firmly rooted in both the academy and the schools. Taken as a whole, the faculty's size and fields of expertise are aligned with the curriculum and student enrollment.

5. Admissions Admissions criteria are designed to recruit students with the capacity and motivation to become successful school leaders.

6. Degrees Graduation standards are high and the degrees awarded are appropriate to the profession.

7. Research Research carried out in the program is of high quality, driven by practice, and useful to practitioners and/or policy makers.

8. Finances Resources are adequate to support the program.

9. Assessment The program engages in continuing self-assessment and improvement of its performance.

The study by Levine (2005) found that the majority of principal preparation programs suffers from curricular disarray, low admissions and graduation standards, weak faculty, inadequate clinical instruction, inappropriate degrees, and poor research. In fact, Levine described the work of education leadership programs as "a race to the bottom," that existed as "a competition among school leadership programs to produce more degrees faster, easier, and more cheaply" (p. 24). Of the over 500 schools and departments of education offering degree-granting graduate programs for school administrators at the time of the study, Levine reported that he could locate only a small number of strong programs in the United States, although none was considered exemplary. The release of the Levine Report depicting the dismal condition of principal preparation shined a flashlight on these programs across the country that could not be ignored.

After the release of the Levine Report (2005), universities, school districts, state departments of education, and the U.S. Department of Education all 
turned their attention to improving the ways in which school leaders were prepared. As a result, expanded preservice internship requirements designed to provide intensive and relevant experiences for aspiring principals have become a new orthodoxy in school reform.

Critics have long argued that traditional preparation programs that rely on coursework alone often fail to link theory with practice, do not reflect the complexities and demands of today's schools, and largely ignore research on leadership development (AACTE, 200I; Copland, I999; Elmore, 2000; IEL, 2000; Lumsden, I992; McCarthy, I999; Murphy \& Vriesenga, 2004; Trapani, 1994). In a national survey of 925 public school principals on the day-to-day realities leaders face, $67 \%$ of principals surveyed claimed, "Typical leadership programs in graduate schools of education are out of touch with the realities of what it takes to run today's school" (Farkas, Johnson, \& Duffett, 2003, p. 39).

Waters et al. (2003) identified leadership practices that significantly increase student achievement, and also found that a principal can negatively impact student growth by focusing on dysfunctional school or classroom practices. Also, research on education leadership programs has empirically connected specific university practices that have been found to improve student achievement (Darling-Hammond, LaPointe, Meyerson, Orr, \& Cohen, 2007). According to that study, effective preparation programs share common features: (a) comprehensive, coherent curriculum aligned to state and professional standards; (b) philosophy and curriculum that emphasize instructional leadership and school improvement; (c) student-centered instruction with pedagogy that integrates theory and practice and stimulates reflection; (d) faculty knowledgeable in subject area, including practitioners with school administration experience; (e) social and professional support in cohorts with expert mentoring and advising; (f) targeted recruitment and selection that proactively bring expert teachers with leadership potential into the principalship; and (g) well-designed, intensive, and supervised internships under the tutelage of expert veterans.

In a recent report from UCEA (Anderson \& Reynolds, 2015, p.I9), several critical practices for a principal preparation program were identified and align with previous research. These critical practices form a framework for policy development:

I. Develop a candidate recruitment and selection strategy that ensures the development of diverse leaders who have been successful educators and have shown potential as leaders. 
2. Provide a clinically rich internship experience that is sustained, indepth, and authentic; synthesizes and applies program knowledge; and develops essential leadership skills.

3. Develop university-district partnerships to collaborate on recruitment and selection, to work together on the professional development of candidates, and to meet the immediate, real-world needs of districts and schools.

4. Ensure a continuous improvement process by designing innovative pedagogy and curriculum to prepare leaders and by responding to local, state, and national standards and expectations

5. Candidate licensure process that requires the candidate to have $3^{+}$ years of teaching experience, possess a master's degree, successfully complete a standards-aligned assessment and portfolio review, and that license renewal be dependent upon meeting specific performance benchmarks.

Anderson and Reynolds (2015) further suggested: "The effectiveness of principal preparation is in part dictated by state policies for principal preparation program approval and candidate licensure" (p. I9). Therefore, it is suggested that state legislators use the framework outlined above to ensure that high leverage and research-based policies are utilized in developing requirements for principal preparation. The first four points are particularly salient for Catholic school principal preparation programs and could help to guide the development of a systematic approach to the preparation and development of Catholic school principals.

Currently, there is no agreed-upon entry-level qualifications for Catholic school principals. Some dioceses require principals to possess state-issued principal credentials, but it is currently unknown how widespread the practice is currently. For example, Catholic school principals in Illinois are generally required by the diocesan offices of Catholic education to possess the appropriate credentials issued by the Illinois State Board of Education. Furthermore, Br. Robert Bimonte, then-president of the National Catholic Education Association (R. Bimonte, personal communication, July Io, 2015) reported that there is no clearinghouse that tracks whether diocesan offices of Catholic Education require state certification/licensure for principals of Catholic schools. Without a consensus on criteria for credentialing within 
the Catholic School sector, offices of Catholic Education are faced with trying to locate candidates from state-accredited programs or alternative certification programs. There are several concerns with that approach. First, how does the state-accredited program also prepare candidates to be successful Catholic school principals when the balance of the program is predominantly focused on the skills required to be successful public school administrators? A second concern revolves around alternative administration certification. Is the alternative certificate perceived as "rigorous" as the standard license, and therefore does it maintain the same face validity as standard licensure/ certification programs? Do the alternative certification programs contain the necessary emphasis on the instructional leadership competencies as it may on the spiritual leadership skills?

\section{The Unique Case of the Catholic School Principal}

The increasing emphasis on the myriad leadership preparation standards (i.e., Interstate School Leaders Licensure Consortium, Southern Regional Education Board, and Educational Leadership Constituent Council) has caused university principal preparation programs to necessarily focus on the more secular aspect of leading schools. For the Catholic school principal, this emphasis has minimized attention to the development of critical strategies to lead for Catholic identity and faith formation. Whereas it is imperative that Catholic school principals be strong instructional leaders, it is just as important that these principals are strong in faith leadership. Bryk, Lee, and Holland (1993) explained how Catholic school principals have a multidimensional role that includes some of the following aspects: instructional leader, financial manager, development and fundraising director, public and alumni relations facilitator, faculty supervisor, student recruitment director, and disciplinarian. Further, Heft (199r), Perri (1989), and others have maintained that the Catholic school principal must be specifically attentive to the faith development of the children entrusted to them.

Church documents clearly state that the role of the Catholic school is to teach students to receive Jesus and live out His call to create the Kingdom of God on earth (Congregation for Catholic Education [CCE], 1977). Additionally, schools are called to fulfill dual functions-religious and academicas described in Church documents (CCE, 1977, 1988). Further, the Code of Canon (Canon 806) calls for Catholic schools to be at least as academically distinguished as their peer institutions, emphasizing the dual role of the 
Catholic school. This calls for a principal that is specifically trained in the Catholic faith as well as in methods to execute the other critical tasks of being a school leader. Hobie et al. (2010) have suggested that the vitality of the school is critically linked to the ability of Catholic leaders to ensure that the Catholic identity of their schools is present, maintained, and enhanced. Earl $(2005$, p. 5I4) discussed this need for balance in all of the roles of the Catholic school principal:

Spiritual leadership is central to the identity of the Catholic school. The Catholic school principal must foster both the religious and academic mission of the Catholic school ... as any principal, the Catholic school principal also monitors the teaching and learning process in all subject areas.

Even with the advent of a national framework of school leadership that is used to inform the creation of principal preparation programs, such a blueprint for the development of Catholic school principals has not emerged. However, a conceptual framework that seems to best describe the unique responsibilities of the Catholic school principal was developed by Ciriello (I998a, I998b, I998c) in a series of works sponsored by the National Catholic Educational Association. Here, Ciriello described the identity of a Catholic school through a tripartite leadership model in which the principal functions as a spiritual, educational, and managerial leader in an integrated way. When all three functions are present, and Catholic values permeate the organizational climate, the school fulfills its catechetical mission. "As architects of Catholic school culture and identity, principals identified their prime roles as determining the quality of religious and academic purposes of their schools and building faith communities among members of their schools" (Belmonte \& Cranston, 2009).

In looking outside of the United States, other conceptual frameworks have been created to address the development of Catholic school principals. The Catholic Education Office of Melbourne (2010) suggested a five-part framework for addressing the professional development needs of principals. This framework focuses on the following action areas: faith, teaching and learning, partnerships, resources, and leadership. The Catholic Education Office in Sydney (2010) suggested six foundations for the formation of Catholic school leaders: religious leadership, leadership for learning, human resources leadership, strategic leadership, and organizational leadership, and personal 
dimensions of leadership. However, an agreed-upon set of standards-based competencies that guides the preparation of Catholic school principals does not really exist as yet.

\section{Preparing Catholic School Principals: The Case for Standards}

It is no secret that contemporary Catholic schools face serious and mounting challenges. Neither is it a secret that passionate, visionary, data-informed Catholic school leaders are essential if schools are going to successfully meet and overcome these challenges, and thrive." (Holter \& Frabutt, 2012).

To be effective, 2Ist-Century Catholic School principals must strike a balance between data-informed decision-making skills and the faith-based leadership skills called for by the various Church documents. As Wallace (1998) observed:

If Catholic schools are to continue to be distinguished by their strong faith communities and not become private schools characterized as schools of academic excellence and a religious memory, attention must be given to faith leadership and how it is being developed in school leadership. (p. 47)

Whereas there is a critical need for preparation in the areas of data-informed decision making, some researchers (O'Keefe, r999; Schuttloffel, 2007) have suggested that "the preponderance of programs for Catholic school administrators are not adequately attentive to the theological and administrative skills, knowledge, and dispositions required of the contemporary Catholic school leader." Of particular concern is the principal's preparation for faith leadership. Schuttloffel's (2003) survey indicated that over half of novice principals lacked the necessary theological or spiritual knowledge to be faith leaders. The statistic rose to $95 \%$ for novice leaders who came from public schools. In another study of Catholic secondary school principals, 70\% responded that their formal coursework did not adequately prepare them to be faith leaders (Joseph, 2002). Principal preparation programs housed in Catholic colleges and universities are the only ones uniquely situated to address this critical role of addressing the development of faith leadership skills. 
Rieckhoff (20I4) noted:

The roles and responsibilities of the Catholic school principal continue to expand as with their public school counterparts, with increasing emphasis on building enrollment, obtaining resources for scholarships, supporting instruction, and serving as the faith leader. The scope of the role of faith leader continues to expand at a challenging time for the Roman Catholic Church, with declining Mass attendance, families not practicing their faith, yet sending their children to a Catholic school, and other examples of disconnectedness with parish life.

With the ever-increasing focus on the enrollment of students in graduate schools, there is an inherent tension between new approaches to principal preparation for public school principals and balancing the unique needs of training effective Catholic school principals. Often, aspiring Catholic school principals can feel that their professional development needs are not addressed. As Cook (2008) described one aspiring principal's observation:

My peers in public schools need only concern themselves with students, discipline, and parents. Everything else is done for them at the district level. I, on the other hand, take care of budgeting, personnel, curriculum, grant writing, school calendar, school maintenance, student recruitment, and the list goes on.

\section{The Intersection Between the NSBECS and Instructional Leadership Standards}

The various leadership standards that are currently used to inform the preparation of school principals are designed to address the leadership needs of developing leaders of public schools. While not a set of leadership standards, the National Standards and Benchmarks for Effective Catholic Elementary and Secondary Schools (NSBECS) (Ozar \& Weitzel-O'Neill, 2oro) might be valuable in developing a set of Catholic school principal competencies that might be useful in the formation of effective faith-based leaderprincipals who are data-informed. Embedded in the NSBECS, critical quality performance indicators for Catholic school principal are suggested.

Even though ISLLC are standards for performance of candidates in training to become principals and NSBECS involves a set of standards and 
indicators of school-level conditions found in effective schools, a certain parallel between the two sets of standards can be extrapolated to create an analysis for areas of commonality and uniqueness. In creating a crosswalk between the NSBECS and the ISLLC (2008) standards, there is a level of congruence that suggests agreement in some of the key activities of the school leader and/or leadership team (see Appendix A). The last column of the table in Appendix A suggests some potential performance indicators.

In comparing the Catholic identity domain of the NSBECS with ISLLC standards I and 5, some conceptual overlap appears. Both of these sets of standards speak to the role of leadership in creating shared vision. However, ISLLC standards I and 5 speak to the vision and mission of education and schools in general, and the NSBECS standards under the Catholic identity domain speak more specifically to the leadership role in mission and vision in relation to advancing the Catholic identity of the organization.

Analysis of the Governance and Leadership domain of the NSBECS and ISLLC standard 4 suggests that both sets of standards acknowledge the role of leadership in forging alliances with various stakeholders toward achieving the vision and mission of the school. There is a strong focus on the collaborative effort and decision-making focused on shared responsibility required for school and student success. Both of these sets of standards suggest the strong need for a focus on results.

Under the Academic Excellence domain of the NSBECS, there is strong overlap with ISLLC Standard 2. Great congruence was found in areas involving the role of leadership in ensuring that a rigorous curriculum is delivered through high quality instruction for all learners. The focus there is on improvements to teaching and learning by creating a culture of high expectations that supports all students. There is also an emphasis on the development and implementation of a continuous improvement process with clear feedback loops to increase learning for all.

Finally, in the NSBECS area of Operational Vitality, there is some intersection found with ISLLC standard 3. Comparison between the NSBECS and ISLLC standards in this area highlights the complexities of the managerial role of the school leader. Whereas the ISLLC standard 3 speaks about the need for operational management, the responsibilities found in the NSBECS standards help to concretize some of the unique managerial tasks as outlined in the literature on the Catholic school principalship (Cook, 2008; Holter \& Frabutt, 2012). 
This analysis suggests that the standards have some overlap and are not necessarily mutually exclusive. Catholic school principal preparation programs can cover the ISSLC standards and focus on the NSBECS standards. By incorporating this overlap within curriculum, Catholic principal preparation programs can address the ISLLC standards to help principal candidates meet eligibility requirements for licensure/accreditation while explicitly addressing the competencies for Catholic school principals suggested by the NCBECS standards.

\section{Toward a Common Agenda for Preparing Principals for Catholic Schools}

Barnett (2005) and Darling-Hammond et al. (2007) suggested that competency-based standards like ISLLC can be used as guidelines for developing research-based curriculum and help to align with the practices necessary for being an effective school leader. Yet no agreed-upon set of standards for the development of Catholic school leaders exists.

This leads to a set of critical questions: Can systematizing the approach to the preparation of Catholic school principals help prepare candidates for the challenges of leading Catholic schools? How can the movement to improve principal preparation for the public schools inform the formation of candidates for the Catholic school as well? The UCEA (Anderson \& Reynolds, 2015) analysis of state programs contains some illustrative lessons for Catholic institutions of higher education (CIHE). As stated earlier, Anderson and Reynolds suggested several policy areas that lead to increased effectiveness in principal preparation (explicit selection process, program standards, clinically rich internships, university partnerships, and program oversight) and have implications for principal preparation programs for Catholic school leaders. Although their report specifically examined policies related to principal preparation programs for public schools, some suggestions can be derived for a Catholic school principal preparation program and offer an agenda for further investigation for Catholic institutions of higher education.

\section{Explicit Selection Process}

Anderson and Reynolds (2015) suggested that principal preparation programs develop a plan for targeted recruitment. They also suggested that the selection process contain performance-based assessments. This model presents a challenge to $\mathrm{CIHE}$ to develop evidenced-based approaches to the recruitment and selection of qualified candidates for the Catholic school 
principalship. As part of a research agenda, CIHE can actively explore the identification of predictors for successful candidates to lead Catholic schools. Can an intentional process of recruitment be developed to identify potential candidates that will be able to excel in the areas of spiritual and academic leadership? Would an explicit process of this nature help to identify candidates and increase the candidate pool? Use of both NSBECS and ISLLC could offer a way to identify the critical variables related to being an effective Catholic school principal. By explicitly aligning a recruitment template with the domains (Catholic identity, governance and leadership, academic excellence and operational vitality) of the NSBECS, potential protocols for recruitment could be created and implemented in partnership with diocesan offices of Catholic education. These protocols can also help shape the selection process. Creating performance-based assessments using the NSBECS/ ISLLC and collecting artifacts that support performance in each of the domains could increase the likelihood of identifying candidates who would make strong Catholic school principals. Without intentionally addressing the critical skills needed to run an effective Catholic school in a direct fashion, principal preparation programs can only rely on the wish of attracting candidates and the bope that they can translate this knowledge and the dispositions within a standard instructional leadership preparation program.

\section{Program Standards}

As suggested earlier, the NSBECS can provide the promise of a standardized framework for the development of Catholic school principals. From the NSBECS and ISLLC, a set of competencies can be identified that provide the basis of a universally agreed-upon set of Catholic school leadership standards that can be used in conjunction with national and/or state-based educational leadership frameworks. The NSBECS can help to articulate the unique set of skills required for the development of Catholic school principals that are equipped for the current realities of Catholic schools. This could, as Barnett (2005) and Darling-Hammond et al. (2007) suggested, develop a standardized curriculum and help to align the critical practices for developing effective Catholic school principals who are both faith leaders and effective instructional leaders. Explicitly addressing the critical elements of spiritual leadership can help to address some of the concerns identified by O'Keefe (1999) by ensuring that the "theological and administrative skills, knowledge, and dispositions required of the contemporary Catholic school leader" are formally addressed within the principal preparation curriculum. 


\section{Clinically Rich Internship}

Anderson and Reynolds (2015) called for internships that are deliberately structured with fieldwork that is tightly integrated with curriculum. The trainee should engage with core leadership responsibilities and supervision should be conducted with an expert mentor. The development of effective Catholic school leaders calls for CIHE to ensure that internships not only focus on the instructional leadership skills, but also look at the spiritual leadership competencies as well as leadership for operational vitality. By creating an explicit focus on these critical skills for the preparation of Catholic school leaders (and articulating performance standards for in-service Catholic school principals), principal preparation programs can increase the intentionality with which they approach this issue. It is possible to use the domains of the NSBECS as an organizing structure for these clinically rich internships for the Catholic school principal. Using the domains of Catholic identity, leadership and governance, academic excellence and operational vitality, critical internship experiences can be designed to garner the Catholic school principal candidate the necessary experiences to grow in these areas. The development of a consensus among CIHE regarding the dimensions of the internship for Catholic school principal candidates can help to inform future research on a "best practice" approach. Having an agreement on the structure of the clinically rich internship experiences can help CIHE identify effective practices that would ultimately increase the effectiveness of the local Catholic school. CIHE should identify a variety of field-based experiences to provide exposure to a wide range of subgroup populations for principal candidates. Instead of serving an internship within one building, possibilities could include exposure to a variety of sites that address the needs of such groups as English-language learners, gifted, and special education populations. Internship experiences should also provide candidates with experiences with students along the learning continuum from prekindergarten to I2th grade. The internship should also include critical experiences in the other domains of the NSBECS. Interns should have directed experience in marketing, enrollment, and development as well as active, on-going participation in the governance structures of the school. Finally, and most critically, how does the internship nurture the faith development of the principal candidate so that they are truly effective faith-based leaders? 


\section{CIHE-Diocesan Partnerships}

In order to ensure that rigorous recruitment and selection of candidates occurs and that clinically rich internships are in place, new structures of collaboration must be developed and maintained between CIHE and diocesan offices of Catholic education. This would call for enhanced participation of the diocesan offices in the selection of candidates and innovative methods of collaboration that would increase the ability of the outreach of CIHE in service of Catholic schools. Potential models of this sort are in place within the public school sector and may serve as possible models for Catholic schools. The Illinois Partnerships Advance Rigorous Training (IL-PART) project, a U.S. Department of Education School Leadership Program grantee, provides an example. IL-PART represents a collective effort between high-need districts and universities that have come together in formal partnerships aimed at transforming leadership preparation and development using a collaborative model. ${ }^{\mathrm{I}}$ In addition to the three qualifying high-need public school district/ university partnerships, IL-PART includes a private school partnership between the Andrew M. Greeley Center For Catholic Education at Loyola University Chicago and the diocesan offices of Catholic education representing Aurora, Bloomington, and Quincy, Illinois.

The consortium of partners collaborate in a two-fold effort aimed at: (a) enhancing the role of the district/university partnerships in creating rigorous and relevant principal training programs aligned to the complexities faced by today's principals; and (b) working collectively to improve teaching and learning and support high academic standards for students in participating high-need districts.

Three clear goals guide the IL-PART Project:

- Goal r: Prepare highly effective school principals and assistant principals that positively impact student learning in high-need districts;

- Goal 2: Develop effective partnerships between university partners and high-need districts to build leadership capacity in an effort to improve student outcomes; and

\footnotetext{
I The qualifying high-need districts and their university partners include: Bloomington District \#87/Illinois State University; East Aurora District \#I3//North Central College; and Quincy District \#172/Western Illinois University.
} 
- Goal 3: Dissemination of IL-PART evaluation findings and emerging best practices in principal preparation and partnership development

There is a mutually beneficial nature to the development of these enhanced university-diocesan partnerships. New forms of collaboration between these two groups could improve the identification of principal candidates through the process of recruitment and candidate selection, as described above. It would be important to examine how these enhanced partnerships impact the number of candidates within the leadership pipeline. Truly rich clinical experiences are hard to implement without access to the array of schools that are under the auspices of the Dioceses. A more explicit process of the internship would require a stronger diocesan voice in the development of the internship experiences. A process of this nature places the diocese in the position of consumer of the principal preparation program. This also has the added benefit of providing on-going in-service support to sitting principals through the exposure to emerging research and/or training on best practices. Through the on-going collaboration of CIHE, dioceses, and Catholic schools, faculty and practitioners reciprocally benefit from sharing expertise. Further, that type of collaborative effort ensures that leadership support doesn't end with graduation, but continues across the development continuum.

The use of the NSBECS alongside ISLLC helps to unify the vocabulary of principal preparation among both dioceses and CIHE. Creating consensus by using a combined structure that incorporates both NSBECS and ISLLC standards assists members of the collaboration by creating common nomenclature and shared understanding of the preparation program outcomes. This has the potential for increasing quality of communication between CIHE and diocesan offices of Catholic education.

\section{Future Directions}

Although the NSBECS is a set of standards that speaks to the organizational quality of Catholic schools, combined with ISLCC, these standards have the promise to identify a framework of behaviors specific to the role of principal that foster effective Catholic school performance. The benefit of having a common framework for principal preparation and on-going development across university training sites has the potential to articulate and advance the unique discipline of the Catholic school principalship. The 
creation of a consensus-based set of principal competencies can focus efforts by CIHE programs to be intentional in the formation of Catholic school principals and to identify and develop evidence-based practices specifically for these types of training programs. Actual performance indicators tied to specific leadership competencies demonstrated by research and correlated with school improvement can be developed by CIHE to support this effort. Building from the combined NSBECS and ISLLC standards, programs can ease the transition for candidates moving from pre- to in-service by providing consistent, comprehensive and graduated performance expectations for aspiring, novice and veteran principals.

There are still questions that require further investigation. A question arises about the connection between the developmental competencies that can be identified within the NSBECS/ISLLC-inspired set of competencies for preservice principals and the on-going professional development needs for in-service principals. A comprehensive set of competencies should account for the professional development needs for the continuum of phases throughout the principalship (e.g., from the aspiring through the retiring phase). Can the creation of an NSBECS/ISLLC-based set of competencies offer this level of comprehensive approach? This could unpack the other important factors in the support of Catholic school principals. What is the nature of partnerships between CIHE and Diocesan offices of Catholic education in the development of mentoring, peer networks, and opportunities to observe other school leaders? This might be critical variable to explore.

Other questions regard the efficacy of an NSBECS/ISLLC-based set of competencies and the development of leaders from public schools who later choose to lead Catholic schools. Are the competencies identified by this framework useful in acculturating former public school principals to the unique job demands of the Catholic school principalship? Can this framework identify critical experiences required for these individuals to successfully transition to the Catholic school setting? How can CIHE and diocesan offices of Catholic education collaborate to bring about these necessary experiences?

To investigate questions of this nature, several structures should be developed. Currently, there is no clearinghouse of data about the credentialing requirements of Catholic school principals and other aspects of the job. Requirements for the position reportedly vary diocese to diocese. In order to systematically investigate this field, it would be critical to develop a central storehouse for this kind of data that is easily accessible to both dioceses and CIHE. Additionally, an open access clearinghouse of this sort could help to 
collect data regarding the various principal preparation programs in $\mathrm{CIHE}$ to disseminate promising practices in training and development and to share evidence-based approaches. This could help facilitate further research into the area of Catholic school principal preparation. As suggested earlier, formalized systems of collaboration (as well as shared resources and tools) among CIHE could help advance a research-based agenda in this area. Exploring the coalition that exists in the Catholic Higher Education in Support of Catholic Schools (CHESCS) professional group as an avenue to develop this sort of collaboration in the service could help to advance this agenda.

As suggested earlier, the field of principal preparation, in general, is under the microscope in order to identify effective practices to create school leaders. The same focus should be placed on principal preparation for Catholic schools. The overlay of NCBECS and ISLLC offers the potential of standardizing an agenda for preparation programs to create a common understanding of essential leadership competencies and indicators that can be used to inform improvement efforts in principal preparation and development dedicated to the formation of the Catholic school principal. It is critical for the future of Catholic schools that effective paths of preparation for school principals, as well as evidence-based approaches to developing principals, are identified to ensure that Catholic schools have leaders who can meet the demands of educating future generations.

\section{References}

American Association of Colleges for Teacher Education. (200I, March). PK-I2 educational leadership and administration. Washington, DC: Author

Anderson, E., \& Reynolds, A. (2015) A policymaker's guide: Research-based policy for principal preparation program approval and licensure. University Council for Educational Administration. Retrieved from http://3 $\mathrm{fl}_{7} \mathrm{Il}_{2} \mathrm{q}$ joj413y6ep2tqpwra. wpengine.netdnacdn.com/wp-content/uploads/20I4/o5/UCEA-State-Policy-Report-website-versionNov2015-v2.pdf

Belmonte, A., \& Cranston, N. (2009). Religious dimension of lay leadership in Catholic education: Preserving Catholic culture in an era of change. Catholic Education: $A$ Journal of Inquiry and Practice, I2(3), 294-319. Retrieved from http://www.eric.ed.gov/ contentdelivery/servlet/ERICServlet?accno=EJ9340I3.

Branch, G., Hanushek, E., \& Rivkin, S. (2009). Estimating principal effectiveness (Working Paper 32.) Washington, DC: National Center for Analysis of Longitudinal Data in Education Research.

Branch, G., Hanushek, E. A., \& Rivkin, S. G. (2013). School leaders matter. Education Next, I3 (2), 62-69. 
Bryk, A. S., Lee, V. E., \& Holland, P. B. (1993). Catholic schools and the common good. Cambridge, MA: Harvard University Press.

Canon Law Society of America. (1983). Code of Canon Law: Latin-English edition. Washington, DC: Canon Law Society of America.

Catholic Education Office of Melbourne. (2010). Educating the whole person. Retrieved from $\mathrm{http} / /$ www.ceomelb.Catholic.edu.au/about-Catholic-education

Catholic Education Office of Sydney. (2010). Catholic schools leadership framework: A vision for the development and practice of leadership. Retrieved from http://www.ceosyd.catholic. edu.au/teachers/learning/documents/dp-leadershipframework.pdf

Ciriello, M. (Ed.). (1998a). Formation and development for Catholic school leaders: The principal as educational leader (Vol. I, and ed.). Washington, DC: United States Conference of Catholic Bishops.

Ciriello, M. (Ed.). (1998b). Formation and development for Catholic school leaders: The principal as spiritual leader (Vol. II, and ed.). Washington, DC: United States Conference of Catholic Bishops.

Ciriello, M (Ed.). (1998c). Formation and development for Catholic school leaders: The principal as managerial leader (Vol. III, 2nd ed.). Washington, DC: United States Conference of Catholic Bishops.

Clotfelter, C., Ladd, H. F., Vigdor, J., \& Wheeler, J. (2006). High-poverty schools and the distribution of teachers and principals. NCL Rev., 85, 1345 .

Cook, T. (2008). Responding to leadership challenges in the US Catholic Schools: The lived reality. Updated keynote address, given at the Third International Conference on Catholic Educational Leadership 2004. Sydney, Australia.

Congregation for Catholic Education. (1977). The Catholic school. Retrieved from http:// www.vatican.va/roman_curia/congregations/ccatheduc/documents/rc_con_ccatheduc_ doc_19770319_catholic-school_en.html

Congregation for Catholic Education. (2007). Educating together in Catholic schools: A shared mission between consecrated persons and the lay faithful. Vatican City: Vatican Publishing. Retrieved from http://www.vatican.va/roman_curia/congregations/ccatheduc/ documents/rc_con_ccatheduc_doc_20070908_educare-insieme_en.html\#Theological_ and_spiritual_formation.

Congregation for Catholic Education. (1997). The Catholic school on the threshold of the third millennium. Vatican City: Vatican Publishing. Retrieved from http://www.vatican.va/ roman_curia/congregations/ccatheduc/documents/rc_con_ccatheducdoc_27041998_ school200o_en.html.

Copland, M. A. (1999). Problem-based learning, problem-framing ability and the principal selves of prospective school principals (Doctoral dissertation). Retrieved from Dissertation Abstracts International, 60/08, 2750.

Cosner, S., \& Jones, M. F. (20I6). Leading school-wide improvement in low-performing schools facing conditions of accountability: Key actions and considerations. Journal of Educational Administration, 54(I), 4I-57. Doi: I0.IIo8/jea-08-20I4-0098

Darling-Hammond, L., LaPointe, M., Meyerson, D., Orr. M. T., \& Cohen, C. (2007). Preparing school leaders for a changing world: Lessons from exemplary leadership development programs. Stanford, CA: Stanford University, Stanford Educational Leadership. 
Doyle, D., \& Locke, G. (2014). Lacking leaders: The challenges of principal recruitment, selection, and placement. New York, NY: Thomas B. Fordham Institute.

Earl, P. H. (2005). Spiritual formation for Catholic educators: Understanding the need. Journal of Catholic Education, 8(4). Retrieved from http://digitalcommons.lmu.edu/ce/ vol8/iss $4 / 6$

Elmore, R. F. (2000). Building a new structure for school leadership (pp. I-46). Washington, DC: Albert Shanker Institute.

Farkas, S., Johnson, J., \& Duffett, A. (2003). Rolling up their sleeves: Superintendents and principals talk about what's needed to fix public schools. New York, NY: Public Agenda.

Hallinger, P., \& Heck, R. (1996). Reassessing the principal's role in school effectiveness; A review of empirical research. Educational Administration Quarterly, 32(I), 5-44.

Hallinger, P., \& Heck, R. (1998). Exploring the principal's contribution to school effectiveness: 1980-1995. School Effectiveness and School Improvement, 9(2), 157-191.

Holter, A. C., \& Frabutt, J. M. (20I2). Mission Driven and Data Informed Leadership. Journal of Catholic Education, ${ }_{15}(2)$. Retrieved from http://digitalcommons.lmu. edu/ce/ volis/iss $2 /$ io

Institute for Educational Leadership Task Force on the Principalship. (2000). Leadership for student learning: Reinventing the principalship. Washington, DC: IEL. Retrieved from http://iel.org/sites/default/files/Leadership-for-Student-Learning-Series-IPrincipal-ıo-200o.pdf

Joseph, E.A. (2002). Faith leadership. In T.C. Hunt, R.J. Nuzzi, \& E.A. Joseph (Eds.), Catholic Schools still make a difference: Ten years of research I99I-200o (pp. 3-8). Washington, DC: National Catholic Educational Association.

Leithwood, K., Seashore Louis, K, Anderson, S., \& Wahlstrom, K. (2004) How leadership influences student learning. Toronto, Ontario: Center for Applied Research and Educational Improvement and Ontario Institute for Studies in Education.

Levine, A. (2005). Educating school leaders. New York, NY: Teachers College, Education School Project.

Lumsden, L. S. (1992). Prospects in principal preparation (ERIC Digest, No. 77). Eugene, OR: ERIC Clearinghouse on Educational Management.

Manna, P. (20I5). developing excellent school principals to advance teaching and learning: Considerations for state policy. New York, NY: The Wallace Foundation.

Marzano, R., Waters, T., \& Mcnulty, B. (2005). School leadership that works: From research to results. Alexandria, VA: Association for Supervision and Curriculum Development.

Murphy, J., \& Vriesenga, M. ( 2004). Research on school leadership preparation in the United States: An analysis (UCEA Monograph Series). Columbia, MO: University Council for Educational Administration.

O’Keefe, J. M. (1999). Leadership in urban Catholic elementary schools. In T. C. Hunt, T. O. Oldenski, \& T. J. Wallace (Eds.), Catholic school leadership: An invitation to lead (pp. 225-243). New York, NY: Falmer Press.

Ozar, L. A., \& Weitzel-O’Neill, P. (Eds.). (2012). National standards and benchmarks for effective Catholic elementary and secondary schools. Chicago, IL: Loyola University Chicago, Center for Catholic School Effectiveness. 
Rieckhoff, B. S. (2014). The Development of Faith Leadership in Novice Principals. Journal of Catholic Education, $I 7(2)$. Retrieved from http://digitalcommons.lmu.edu/ce/volry/iss $/ 3$

Robinson, V. M., Lloyd, C. A., \& Rowe, K. J. (2008). The impact of leadership on student outcomes: An analysis of the differential effects of leadership types. Educational Administration Quarterly, 44(5), 635-674. doi: 10.1177/0013161х08321509

Seashore L., Dretzke, B., \& Wahlstrom, K. (20Iо). How does leadership affect student achievement? Results from a national US survey. School Effectiveness and School Improvement: An International Journal of Research, Policy and Practice, 2I(3), 315-336.

Schuttloffel, M. (2003) Report on the future of Catholic school leadership. Washington, DC: National Catholic Education Association.

Schuttloffel, M. (2007). Contemporary challenges to the recruitment, formation, and retention of Catholic school leadership in the USA. In G. Grace \& J. O'Keefe (Eds.), International handbook of Catholic education: Challenges for school systems in the 2Ist century (Vol. I, pp. 85-IO2). Dordrecht, The Netherlands: Springer.

Trapani, V.M. (1994). Field experiences in administrative preparation programs for elementary school principals: Perceived effectiveness (Doctoral dissertation). Dissertation Abstracts, 55/12, 3710.

University of Notre Dame Task Force. (2006). Making God known, loved, and served: The future of Catholic primary and secondary schools in the United States: Final report. Notre Dame, IN: University of Notre Dame. Retrieved from http://ace.nd.edu/files/task_ force_report.pdf.

Wallace, T. J. (1998). The faith leadership issue. Momentum, 29, 46-49.

Waters, T., Marzano, R.J., \& McNulty, B. (2003). Balanced leadership: What 30 years of research tells us about the effect of leadership on student achievement. Aurora, CO: Mid-Continent Research for Education and Learning.

Witziers, B., Bosker, R. J., \& Kruger, M. L. (2003). Educational leadership and student achievement: The elusive search for an association. Educational Leadership Quarterly, $39(3), 398-425$.

Michael J. Boyle, Ph.D., is Clinical Assistant Professor and Director of the Andrew M. Greeley Center for Catholic Education at Loyola University Chicago. Correspondence regarding this article can be directed to Dr. Boyle at mboylez@luc.edu

Alicia Haller, Ph.D., is the IL-PART Co-Director at the Center for the Study of Education Policy at Illinois State University.

Erika Hunt, Ph.D. is a Senior Policy Analyst and Research at the Center for the Study of Education Policy at Illionis State University. 


\section{Appendix A: Crosswalk between NSBECS and ISLLC Standards}

\begin{tabular}{|c|c|c|}
\hline $\begin{array}{l}\text { National Standards for } \\
\text { Effective Catholic Schools }\end{array}$ & $\begin{array}{l}\text { Interstate School Leader } \\
\text { Licensure Consortium } \\
\text { (ISLLC) Standards for School } \\
\text { Leaders } 2008\end{array}$ & $\begin{array}{l}\text { Examples of Indicators } \\
\text { Across All Standards }\end{array}$ \\
\hline \multicolumn{3}{|l|}{$\begin{array}{l}\text { Mission and Catholic } \\
\text { Identity }\end{array}$} \\
\hline $\begin{array}{l}\text { Driven by a clearly } \\
\text { communicated mission } \\
\text { that embraces a Catholic } \\
\text { identity rooted in gospel, } \\
\text { values, centered on the } \\
\text { Eucharist, and committed } \\
\text { to faith formation, } \\
\text { academic excellence and } \\
\text { service. }\end{array}$ & $\begin{array}{l}\text { Standard } 1 \text {. Promotes } \\
\text { the success of every } \\
\text { student by facilitating the } \\
\text { development, articulation, } \\
\text { implementation, and } \\
\text { stewardship of a vision } \\
\text { of learning that is shared } \\
\text { and supported by all } \\
\text { stakeholders. }\end{array}$ & \multirow{4}{*}{$\begin{array}{l}\text { Collaboratively develops } \\
\text { and implements a shared } \\
\text { vision and mission; } \\
\text { Collects and uses } \\
\text { data to identify goals, } \\
\text { assess organizational } \\
\text { effectiveness, and promote } \\
\text { organizational learning; } \\
\text { Creates and implements } \\
\text { plans to achieve goals; } \\
\text { Promotes continuous and } \\
\text { sustainable improvement; } \\
\text { Monitors and evaluates } \\
\text { progress and revise plans. }\end{array}$} \\
\hline $\begin{array}{l}\text { Rigorous academic program } \\
\text { for religious studies and } \\
\text { catechesis in the Catholic } \\
\text { faith, set within a total } \\
\text { academic curriculum that } \\
\text { integrates faith, culture, } \\
\text { and life. }\end{array}$ & & \\
\hline $\begin{array}{l}\text { Provides opportunities } \\
\text { outside the classroom for } \\
\text { student faith formation, } \\
\text { participation in liturgical } \\
\text { and communal prayer, and } \\
\text { action in service of social } \\
\text { justice. }\end{array}$ & $\begin{array}{l}\text { Standard } 5 \text {. Promotes the } \\
\text { success of every student } \\
\text { by acting with integrity, } \\
\text { fairness, and in an ethical } \\
\text { manner. }\end{array}$ & \\
\hline $\begin{array}{l}\text { Provides opportunities for } \\
\text { adult faith formation and } \\
\text { action in service of social } \\
\text { justice. }\end{array}$ & & \\
\hline
\end{tabular}




\begin{tabular}{|c|c|c|}
\hline Governance and Leadership & & \\
\hline $\begin{array}{l}\text { Governing body (person or } \\
\text { persons) that recognizes } \\
\text { and respects the role(s) } \\
\text { of the appropriate and } \\
\text { legitimate authorities, } \\
\text { and exercises responsible } \\
\text { decision making in } \\
\text { collaboration with the } \\
\text { leadership team for } \\
\text { development and oversight } \\
\text { of the school's fidelity } \\
\text { to mission, academic } \\
\text { excellence, and operational } \\
\text { vitality. }\end{array}$ & \multirow[t]{2}{*}{$\begin{array}{l}\text { Standard } 4 \text {. Promotes the } \\
\text { success of every student by } \\
\text { collaborating with faculty } \\
\text { and community members, } \\
\text { responding to diverse } \\
\text { community interests and } \\
\text { needs, and mobilizing } \\
\text { community resources }\end{array}$} & \multirow[t]{2}{*}{$\begin{array}{l}\text { Collaborative effort and } \\
\text { decision-making focused } \\
\text { on shared responsibility } \\
\text { for school and student } \\
\text { success; } \\
\text { Engages stakeholders } \\
\text { around improvements } \\
\text { efforts aligned to the } \\
\text { school's mission and vision } \\
\text { and focused on results. }\end{array}$} \\
\hline $\begin{array}{l}\text { Qualified leader/leadership } \\
\text { team empowered by the } \\
\text { governing body to realize } \\
\text { and implement the school's } \\
\text { mission and vision. }\end{array}$ & & \\
\hline Academic Excellence & & \\
\hline $\begin{array}{l}\text { Clearly articulated rigorous } \\
\text { curriculum aligned with } \\
\text { relevant standards, } 21 \text { st- } \\
\text { century skills, and gospel } \\
\text { values, implemented } \\
\text { through effective } \\
\text { instruction. }\end{array}$ & \multirow{2}{*}{$\begin{array}{l}\text { Standard 2. Promotes the } \\
\text { success of every student } \\
\text { by advocating, nurturing, } \\
\text { and sustaining a school } \\
\text { culture and instructional } \\
\text { program conducive to } \\
\text { student learning and staff } \\
\text { professional growth }\end{array}$} & \multirow{2}{*}{$\begin{array}{l}\text { Focuses on improved } \\
\text { teaching and learning } \\
\text { through a rigorous } \\
\text { curriculum; } \\
\text { Creates a culture of high } \\
\text { expectations that provides } \\
\text { supports for all students; } \\
\text { implementation of a } \\
\text { continuous improvement } \\
\text { process with clear feedback } \\
\text { loops }\end{array}$} \\
\hline $\begin{array}{l}\text { Uses school-wide } \\
\text { assessment methods and } \\
\text { practices to document } \\
\text { student learning and } \\
\text { program effectiveness, to } \\
\text { make student performances } \\
\text { transparent, and to } \\
\text { inform the continuous } \\
\text { review of curriculum } \\
\text { and the improvement of } \\
\text { instructional practices. }\end{array}$ & & \\
\hline
\end{tabular}


316 Journal of Catholic Education / May 2016

\begin{tabular}{|c|c|c|}
\hline $\begin{array}{l}\text { Provides programs and } \\
\text { services aligned with the } \\
\text { mission to enrich the } \\
\text { academic program and } \\
\text { support the development of } \\
\text { student and family life. }\end{array}$ & $\begin{array}{l}\text { Standard } 6 \text {. Promotes the } \\
\text { success of every student by } \\
\text { understanding, responding } \\
\text { to, and influencing the } \\
\text { political, social, economic, } \\
\text { legal, and cultural context }\end{array}$ & $\begin{array}{l}\text { Aligns school improvement } \\
\text { efforts with the school's } \\
\text { mission and vision; } \\
\text { Coordinates the work of } \\
\text { multiple stakeholders } \\
\text { focused on school } \\
\text { improvement efforts. }\end{array}$ \\
\hline Operational Vitality & & \\
\hline $\begin{array}{l}\text { Provides a feasible three to } \\
\text { five year financial plan that } \\
\text { includes both current and } \\
\text { projected budgets and is } \\
\text { the result of a collaborative } \\
\text { process, emphasizing } \\
\text { faithful stewardship. }\end{array}$ & \multirow{4}{*}{$\begin{array}{l}\text { Standard } 3 \text {. Promotes the } \\
\text { success of every student by } \\
\text { ensuring management of } \\
\text { the organization, operation, } \\
\text { and resources for a safe, } \\
\text { efficient, and effective } \\
\text { learning environment. }\end{array}$} & \multirow{4}{*}{$\begin{array}{l}\text { Aligns all resources toward } \\
\text { the school's mission and } \\
\text { vision; } \\
\text { Ensures compliance with all } \\
\text { educational requirements } \\
\text { and accountable for school } \\
\text { and student outcomes; } \\
\text { Allocates resources to } \\
\text { maintain facilities, ensure } \\
\text { a safe, clean and effective } \\
\text { learning environment; }\end{array}$} \\
\hline $\begin{array}{l}\text { Operates in accord with } \\
\text { published human resource/ } \\
\text { personnel policies } \\
\text { developed in compliance } \\
\text { with (arch) diocesan } \\
\text { policies and/or religious } \\
\text { congregation sponsorship } \\
\text { policies, which affect all } \\
\text { staff and provide clarity } \\
\text { for responsibilities, } \\
\text { expectations and } \\
\text { accountability. }\end{array}$ & & \\
\hline $\begin{array}{l}\text { Develops and maintains a } \\
\text { facilities, equipment, and } \\
\text { technology management } \\
\text { plan designed to } \\
\text { continuously support the } \\
\text { implementation of the } \\
\text { educational mission of the } \\
\text { school }\end{array}$ & & \\
\hline $\begin{array}{l}\text { Enacts a comprehensive } \\
\text { plan, based on a } \\
\text { compelling mission, for } \\
\text { institutional advancement } \\
\text { through communications, } \\
\text { marketing, enrollment } \\
\text { management, and } \\
\text { development. }\end{array}$ & & \\
\hline
\end{tabular}

